\title{
The Film of Chitosan-ZnO Nanoparticles-CTAB : Synthesis, Characterization and In Vitro Study
}

\author{
Ahmad Fatoni ${ }^{1 *}$, Herlina Silvia Yessica ${ }^{2}$, Aldilah $^{2}$, Mia Almi $^{2}$, Agnes Rendowaty $^{1}$, Romsiah $^{1}$, Lasmaryna Sirumapea $^{1}$, Nurlisa Hidayati $^{3}$ \\ ${ }^{1}$ Bhakti Pertiwi High School of Pharmacy Science, Palembang 30128, Indonesia \\ ${ }^{2}$ Undergraduate of Bhakti Pertiwi High School of Pharmacy Science, Palembang 30128, Indonesia \\ ${ }^{3}$ Department of Chemistry, Faculty of Mathematic and Natural Sciences, Sriwijaya University, Palembang 30862, Indonesia \\ *Corresponding author: ahfatoni@yahoo.com
}

\begin{abstract}
The casting method was used for the synthesis of film chitosan-ZnO nanoparticles-CTAB. The Analysis of the functional groups of film chitosan-ZnO nanoparticles-CTAB with FTIR spectroscopy and its physical structure with X-ray diffraction. The method of agar disk diffusion was used to this film for study as an antibacterial of Staphylococcus aureus. The functional groups of $\mathrm{Zn}-\mathrm{O}$ at the film of chitosan-ZnO nanoparticles-CTAB were detected at wavenumber between $578-619 \mathrm{~cm}^{-1}$. The band at $2852.72-2854.65$ $\mathrm{cm}^{-1}$ is the band of $\mathrm{C}-\mathrm{H}$ groups in the film of chitosan-ZnO nanoparticles-CTAB. The influence of ZnO nanoparticles-CTAB changed the physical structure of chitosan. The inhibition zone in the film of chitosan-ZnO nanoparticles-CTAB I, II, and III was $10.37 \pm 0.55$, $11.31 \pm 1.27$, and $10.38 \pm 0.24 \mathrm{~mm}$ respectively.
\end{abstract}

Keywords

Film of chitosan-ZnO nanoparticles-CTAB, Staphylococcus aureus

Received: 20 September 2021, Accepted: 23 December 2021

https://doi.org/10.26554/sti.2022.7.1.58-66

\section{INTRODUCTION}

The one of an organic polymer is chitosan and chitosan was obtained by the deacetylation reaction process of chitin. This process can be done by adding alkali solution and finally, the acetyl groups $\left(\mathrm{COCH}_{3}\right)$ can be removed from the chitin structure. Chitosan has a structure formula $\mathrm{C}_{6} \mathrm{H}_{11} \mathrm{O}_{4} \mathrm{~N}$ because every monomer has one primary amine and two free hydroxyl groups (Goy et al., 2016). The properties of chitosan can be enhanced by modification via chemically or physically of these primary amine groups (Cheba, 2020) and hydroxyl groups (Brasselet et al., 2019). This modification aims to enhance the biological and chemical properties of chitosan and the chitosan modified can be used in any field such as in foods, environmental, material, cosmetic, pharmaceutical, and biomedical (Brasselet et al., 2019).

The researchers used the metal oxide nanoparticles as the modifier agent of chitosan such as $\mathrm{ZnO}$ (Dananjaya et al., 2018; Fatoni et al., 2020b; Fatoni et al., 2020a; Fatoni et al., 2021), $\mathrm{CuO}$ nanoparticles (Fatoni et al., 2020), and $\mathrm{AgO}$ nanoparticles (Hajji et al., 2019) because the primary amine groups of chitosan can be reacted with metal oxide nanoparticles (Usman et al., 2012; Haldorai and Shim, 2013; Abdelhady, 2012). Application of chitosan modified metal oxide nanoparticles was studied by researchers such as antibacterial (Dananjaya et al., 2018; Fatoni et al., 2020b; Fatoni et al., 2020a; Fatoni et al., 2020; Fatoni et al., 2021; Hajji et al., 2019), dye degradation (Preethi et al., 2020), adsorbent (Muinde et al., 2020) and analytical sensor (Nainggolan et al., 2020).

The properties of metal oxide nanoparticles can be enhanced by adding cetyltrimethylammonium bromide (CTAB, $\left.\mathrm{C}_{19} \mathrm{H}_{42} \mathrm{BrN}\right)$. Metal oxide such as $\mathrm{AgO}$ nanoparticles was synthesized by the green method and this product was modified by CTAB (Jang et al., 2015; Al-Thabaiti et al., 2015; Khan et al., 2012). The $\mathrm{ZnO}$ nanoparticles can be modified by CTAB with several methods such as hydrothermal (Geetha and Thilagavathi, 2010; Narayanan and Karthigeyan, 2016Ramimoghadam et al., 2012), calcination method (Medina et al., 2018), pulsed laser ablation (Abdi and Dorranian, 2018) and sol-gel (Khan et al., 2016). The mechanism of interaction between $\mathrm{CTAB}$ and metal nanoparticles is the non-polar chain of CTAB will interact with the hydrophobic layer of the metal nanoparticles and the polar groups from CTAB are facing out, stabilizing the particles in aqueous media (Guivar et al., 2015). The metal oxide nanoparticles-CTAB can be used such as antibacterial (Tamuly et al., 2013), therapeutic and/or diagnostic applications (Medina et al., 2018).

Recently, chitosan can be shaped into chitosan film. Chi- 
tosan film has an advantage such as flexibility but it has limitations such as low regeneration (Estevam et al., 2012; Rodrigues et al., 2018). ZnO nanocomposite can act as modifier agent of chitosan to be chitosan- $\mathrm{ZnO}$ nanocomposite film (Rahman et al. , 2018; Qiu et al., 2019). Although the above studies on chitosan film modified $\mathrm{ZnO}$ nanoparticles have well been published but there is a little study of the chitosan was combined by metal nanoparticles and CTAB in a film form as a product. Modification of chitosan with $\mathrm{ZnO}$ nanoparticles-CTAB in the film form is expected to increase the flexibility of chitosan. The ability of chitosan as an antibacterial agent can be enhanced by adding the $\mathrm{ZnO}$ nanoparticles and CTAB. This assumption based on chitosan can act as antibacterial (Benhabiles et al., 2012), CTAB can change the surface properties of $\mathrm{ZnO}$ nanoparticles such as surface charge (Siboni et al., 2015) and it has an effect to increase the antibacterial activity (Jang et al., 2015).

This study was aimed to modify the chitosan using $\mathrm{ZnO}$ nanoparticles-CTAB to be a film of chitosan-modified $\mathrm{ZnO}$ nanoparticles-CTAB. The effect of both chitosan and $\mathrm{ZnO}$ nanoparticles-CTAB was studied. The film of $\mathrm{ZnO}$ nanopartic les-CTAB was prepared by casting method and it was analyzed by Fourier transform infrared spectroscopy and X-ray diffraction. Antibacterial activity of film chitosan- $\mathrm{ZnO}$ nanoparticlesCTAB to Staphylococcus aureus (S. aureus) was investigated by the agar diffusion method.

\section{EXPERIMENTAL SECTION}

\subsection{Materials and Instruments}

All chemicals are purchased from Merck such as zinc acetate dihydrate $\left(\mathrm{Zn}\left(\mathrm{CH}_{3} \mathrm{COO}\right)_{2} \cdot 2 \mathrm{H}_{2} \mathrm{O}\right)$, cetyltrimethyl-ammonium bromide (CTAB, $\left[\mathrm{CH}_{3}\left(\mathrm{CH}_{2}\right)_{15} \mathrm{~N}(\mathrm{Br})\left(\mathrm{CH}_{3}\right)_{3}\right]$ ), sodium hydroxide $(\mathrm{NaOH})$, nutrient agar, and acetic acid glacial $\left(\mathrm{CH}_{3} \mathrm{COOH}\right)$. Chitosan with a deacetylation degree of $87 \%$, purchased from local industry (CV. Ocean Fresh Bandung). Aquadest and bacteria of $S$. aureus are obtained from laboratory of our institution. Guava seed of leaf (Psidium guajava L) from Palembang city, province of South Sumatera. The specification of FTIR Spectrophotometer and XRD is the Shimadzu Prestige-21 and Shimadzu 6000 respectively.

\subsection{Preparation of Aqueous Leaf Extract of Guava Seed}

The procedure from Daphedar and Taranath (2018) with slight modification was used in the preparation of an aqueous extract of guava seed leaf. A small shape of cleaned leaves of guava seed $(50 \mathrm{~g})$ was added into $500 \mathrm{~mL}$ of beaker glass that containing $250 \mathrm{~mL}$ of aquadest and heated at $90^{\circ} \mathrm{C}$ (30 minutes). After 30 minutes, the beaker glass was let until cold. The filtrate was used for biosynthesis procedure.

\subsection{Biosynthesis of $\mathrm{ZnO}$ nanoparticles-CTAB}

$\mathrm{ZnO}$ nanoparticles-CTAB was biosynthesized by procedure of Nasrollahzadeh et al. (2017) with slight modification. About $150 \mathrm{~mL}$ of aqueous leaf extract of guava seed was mixed to 50 $\mathrm{mL}$ of $\mathrm{Zn}\left(\mathrm{CH}_{3} \mathrm{COO}\right)_{2} \cdot 2 \mathrm{H}_{2} \mathrm{O}$ solution $(0.1 \mathrm{M})$ at erlenmeyer flask $250 \mathrm{~mL} .0 .728 \mathrm{~g}$ of CTAB was added to this mixture. All the mixture was heated on a hot plate at $60^{\circ} \mathrm{C}$ and stirred continuously for 30 minutes. The mixture was allowed to cool at room temperature and added of solution $\mathrm{NaOH} 0.1$ $\mathrm{M}$ with stirring continuously until $\mathrm{pH} 8$. The mixture was kept until the precipitation appeared (6-12 hours). A top is a filtrate and the bottom is a solid of $\mathrm{ZnO}$ nanoparticles-CTAB. $\mathrm{ZnO}$ nanoparticles-CTAB was rinsed with $15 \mathrm{~mL}$ of aquadest before dried at $50^{\circ} \mathrm{C}$ ( $4-5$ hours). The comparison of volume between aqueous leaf extract of guava seed $(\mathrm{mL})$ and $0.1 \mathrm{M}$ of $\mathrm{Zn}\left(\mathrm{CH}_{3} \mathrm{COO}\right)_{2} \cdot 2 \mathrm{H}_{2} \mathrm{O}$ solution $(\mathrm{mL})$ was made by the same procedure and tabulated in Table 1.

Table 1. Biosynthesis of $\mathrm{ZnO}$ Nanoparticles-CTAB

\begin{tabular}{ccccc}
\hline No & Type & $\begin{array}{c}\text { Aqueous leaf extract } \\
\text { of guava seed }(\mathrm{mL})\end{array}$ & CTAB $(\mathrm{g})$ & $\begin{array}{c}\mathrm{Zn}\left(\mathrm{CH}_{3} \mathrm{COO}\right)_{2} \cdot 2 \mathrm{H}_{2} \mathrm{O} \\
\text { solution }(0.1 \mathrm{M}, \mathrm{mL})\end{array}$ \\
\hline 1 & A & 50 & 0.728 & 150 \\
2 & B & 100 & 0.728 & 100 \\
3 & C & 150 & 0.728 & 50 \\
\hline
\end{tabular}

\subsection{Fabrication of The Film Chitosan- $\mathrm{ZnO}$ Nanoparticles- CTAB}

All film was made by casting method and adopted from Jayasuriya et al. (2013). Chitosan film (as control, 1\% w/v) was prepared by dissolving $0.1 \mathrm{~g}$ of chitosan powder in acetic acid $(1 \% \mathrm{v} / \mathrm{v}, 10 \mathrm{~mL})$ solution at $250 \mathrm{~mL}$ of beaker glass, the mixture was continuously stirred (room temperature, $1 \mathrm{~h}$ ). This solution was moved into a petri dish and kept at room temperature until dry. For the fabrication of film chitosan- $\mathrm{ZnO}$ nanoparticles-CTAB (Film I), chitosan powder $(0.1 \mathrm{~g})$ was added in acetic acid solution $(1 \% \mathrm{v} / \mathrm{v}, 10 \mathrm{~mL})$ at $250 \mathrm{~mL}$ of beaker glass by continuous stirring for $1 \mathrm{~h}$ (room temperature). The $\mathrm{ZnO}$ nanoparticles-CTAB (type A, $0.1 \mathrm{~g}$ ) were mixed into the beaker glass. The mixture was shaken by continuously stirring at room temperature for $1 \mathrm{~h}$. The mixture was moved into a petri dish and kept at room temperature until dry. Chitosan film and film of chitosan- $\mathrm{ZnO}$ nanoparticles-CTAB were saved in a desiccator for the next experiment. Film II and III were prepared with the same procedure and tabulated in Table 2.

Table 2. The Comparison Between Chitosan and $\mathrm{ZnO}$ Nanoparticles-CTAB in The Synthesis Film of Chitosan-ZnO Nanoparticles-CTAB

\begin{tabular}{ccc}
\hline Film & $\begin{array}{c}\text { The comparison } \\
\text { chitosan }(\mathrm{g})\end{array}$ & $\begin{array}{c}\mathrm{ZnO} \text { nanoparticles } \\
\text { CTAB }(\mathrm{g})\end{array}$ \\
\hline I & 0.1 & 0.1 (type A) \\
II & 0.1 & 0.2 (type B) \\
III & 0.2 & 0.1 (type C) \\
\hline
\end{tabular}

\subsection{Characterization}

FTIR Spectrophotometer was used for the analysis of the functional group of chitosan film, CTAB, $\mathrm{ZnO}$ nanoparticles- 
CTAB (type A, B, and $\mathrm{C}$ ), and film of chitosan- $\mathrm{ZnO}$ nanoparti cles-CTAB (Film I, II, and III). The crystallite size of $\mathrm{ZnO}$ nanoparticles-CTAB (type A, B, and $\mathrm{C}$ ) and evaluating the crystalline level of chitosan film and film of chitosan- $\mathrm{ZnO}$ nanoparticles-CTAB (Film I, II, and III) were based on the diffractogram. The diffractogram was obtained from the analysis of the sample with X-ray diffraction. The operation procedure of FTIR Spectrophotometer and X-ray diffraction are referring to sample characterization as reported by Fatoni et al. (2021).

\subsection{The Application of Film Chitosan-ZnO Nanoparticles- CTAB to $S$. aureus}

Three Petri dishes were used in this experiment. The procedure to prepare the inoculum suspension of $S$. aureus was adopted by Isnaeni et al. (2020). The preparation of nutrient agar for used application of film chitosan- $\mathrm{ZnO}$ nanoparticlesCTAB and ready to use are referred to Fatoni et al. (2021) procedure. The film of chitosan- $\mathrm{ZnO}$ nanoparticles-CTAB (a film I, II, and III) and chitosan film was prepared as the sterile of paper disks with a diameter of $6 \mathrm{~mm}$ respectively and pasted aseptically on the second layer. The incubation of the all samples was done at $37^{\circ} \mathrm{C}(24 \mathrm{~h})$. After $24 \mathrm{~h}$, the clear zone from the effect of film of chitosan- $\mathrm{ZnO}$ nanoparticles-CTAB (a film I, II, and III) and chitosan film was observed and measured respectively.

\section{RESULTS AND DISCUSSION}

\subsection{Biosynthesis of ZnO Nanoparticles-CTAB}

Aqueous extract of leaves guava seed, sodium hydroxide, CTAB, and $\mathrm{Zn}\left(\mathrm{CH}_{3} \mathrm{COO}\right)_{2} \cdot 2 \mathrm{H}_{2} \mathrm{O}$ solution are the materials on this biosynthesis. Aqueous extracts of leaves guava seed are containing biomolecules as reported by Joseph et al. (2016). ZnO nanoparticles-CTAB was biosynthesized in $\mathrm{pH} 8$ because the biomolecules are not active under acidic conditions (Ibrahim, 2015), but at $\mathrm{pH} \mathrm{8,} \mathrm{the} \mathrm{biomolecules} \mathrm{in} \mathrm{aqueous} \mathrm{extract} \mathrm{of}$ leaves guava seed maybe will affect the ability to change the electrical charges of biomolecules as capping and stabilizing agent (Khalil et al. , 2014). The mechanism reaction between aqueous extract of leaves guava seed, sodium hydroxide, CTAB, and zinc acetate dihydrate solution is below (Junior et al., 2017):

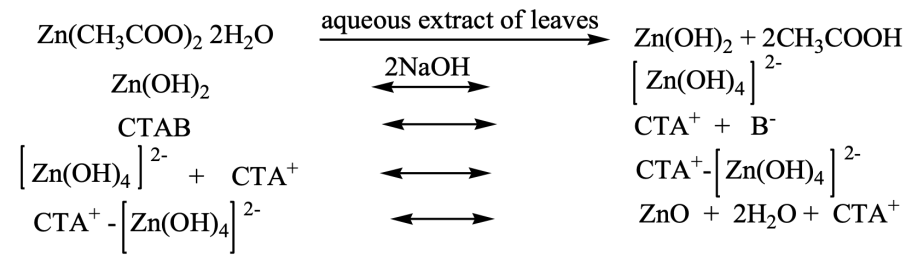

Zinc acetate dihydrate solution is the precursor and aqueous extract of leaves guava seed as media will be hydrolyzed to $\mathrm{Zn}(\mathrm{OH})_{2} . \mathrm{Zn}(\mathrm{OH})_{2}$ in alkaline solution will form $\left[\mathrm{Zn}(\mathrm{OH})_{4}\right]^{2-}$ complex. $\mathrm{CTA}^{+}$dan $\mathrm{B}^{-}\left(\mathrm{Br}^{-}\right.$ion) will be formed from $\mathrm{CTAB}$. The reaction between positive charge of $\mathrm{CTA}^{+}$and $\left[\mathrm{Zn}(\mathrm{OH})_{4}\right]^{2-}$ complex will form of $\mathrm{CTA}^{+}-\left[\mathrm{Zn}(\mathrm{OH})_{4}\right]^{2-}$ complex. Finally,
$\mathrm{CTA}^{+}-\left[\mathrm{Zn}(\mathrm{OH})_{4}\right]^{2-}$ is changed to $\mathrm{ZnO}, \mathrm{H}_{2} \mathrm{O}$ and $\mathrm{CTA}^{+}$ion (Junior et al., 2017). Figure 1 is the photograph of types A, B, and $\mathrm{C}$ of $\mathrm{ZnO}$ nanoparticles-CTAB.

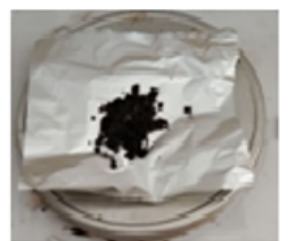

a

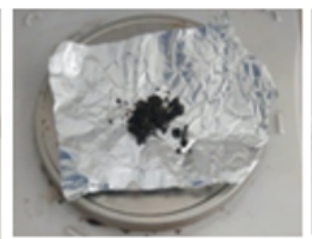

b

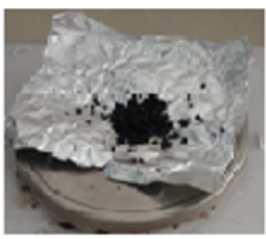

c
Figure 1. The Photograph of $\mathrm{ZnO}$ Nanoparticles-CTAB, Type A (a), Type B (b), and Type C (c)

\subsection{Synthesis of The Film Chitosan- $\mathrm{ZnO}$ Nanoparticles-CT} $\mathrm{AB}$

The principle of this synthesis is the reaction between metals (such as $\mathrm{ZnO}$ ) and $\mathrm{N}-\mathrm{H}$ or $\mathrm{O}-\mathrm{H}$ groups in the chitosan structure via the covalent bond (Daphedar and Taranath, 2018; Muinde et al., 2020; Chen et al., 2019). The photograph of film chitosan- $\mathrm{ZnO}$ nanoparticles-CTAB as a film I, II, and III as seen in Figure 2. The synthesis of film of chitosan- $\mathrm{ZnO}$ nanoparticles-CTAB was illustrated by Wu and Zhang (2018) with slight modification and illustrated in Figure 3.

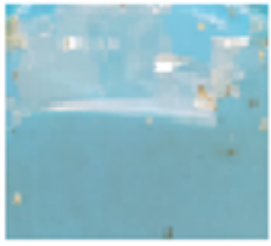

a

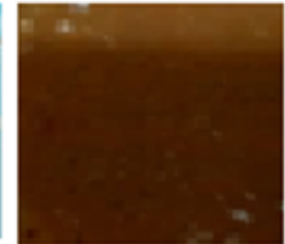

b
Figure 2. The Photograph of Film Chitosan- $\mathrm{ZnO}$ Nanoparticles-CTAB, Film I (a), Film II (b), and Film III (c)

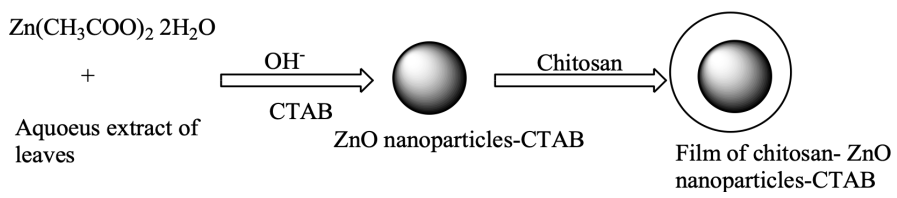

Figure 3. Illustration of The Preparation Film Chitosan- $\mathrm{ZnO}$ Nanoparticles-CTAB

\subsection{Analysis of Functional Groups}

The functional groups analysis of $\mathrm{CTAB}$ and $\mathrm{ZnO}$ nanoparticlesCTAB (type A, B and C) as seen in Figure 4, 5 and tabulated in Table 3.

The stretching vibration of $-\mathrm{CH}_{2}$ asymmetric and symmetric are observed at 2918.30 and $2848.86 \mathrm{~cm}^{-1}$ respectively. 
Table 3. Analysis of The Functional Groups CTAB and $\mathrm{ZnO}$ Nanoparticles-CTAB

\begin{tabular}{|c|c|c|c|c|c|}
\hline \multirow{2}{*}{ No. } & \multirow[t]{2}{*}{$\begin{array}{l}\text { The Functional } \\
\text { Groups }\end{array}$} & \multirow{2}{*}{ CTAB } & \multicolumn{3}{|c|}{$\begin{array}{l}\text { Wave number }\left(\mathrm{cm}^{-1}\right) \\
\quad \mathrm{ZnO} \text { nanoparticles-CTAB }\end{array}$} \\
\hline & & & Type A & Type B & Type C \\
\hline 1 & $\mathrm{O}-\mathrm{H} / \mathrm{N}-\mathrm{H}$ & & 3423.65 & 3421.72 & 3419.79 \\
\hline 2 & C-O-C & & 1610.56 & 1579.7 & 1566.2 \\
\hline 3 & C-H asymmetric & 2918.3 & 2918.3 & 2920.23 & 2916.37 \\
\hline 4 & C-H symmetric & 2848.9 & 2850.86 & 2850.79 & 2848.86 \\
\hline 5 & $\mathrm{~N}-\mathrm{CH}_{3}$ asymmetric & 1481.3 & 1469.76 & - & 1481.33 \\
\hline 6 & $\mathrm{~N}-\mathrm{CH}_{3}$ symmetric & 1400.3 & 1409.96 & 1409.96 & 1409.96 \\
\hline 7 & $\mathrm{~N}-\mathrm{CH}_{3}$ & 3014.7 & - & - & - \\
\hline 8 & $\mathrm{C}-\mathrm{N}$ & 908.47 & 910.4 & 910.4 & 910.4 \\
\hline 10 & $\mathrm{Zn}-\mathrm{O}$ & - & 617.22 & 619.15 & 621.08 \\
\hline
\end{tabular}

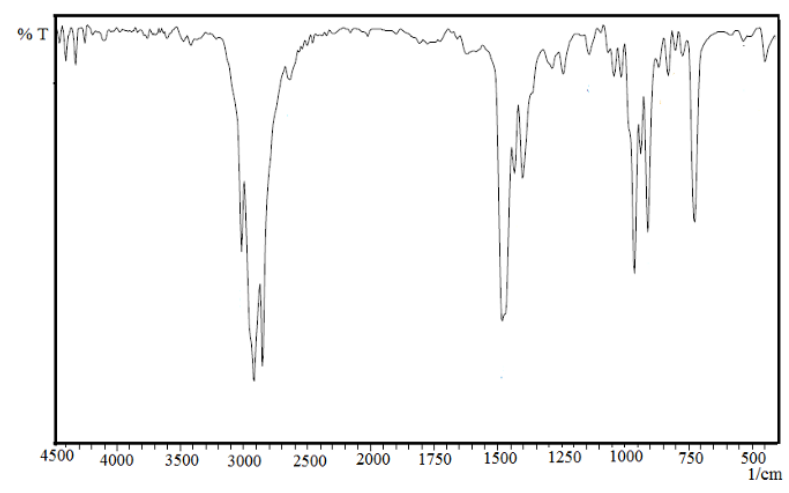

Figure 4. FTIR Spectra of CTAB

The bending vibration of $\mathrm{N}-\mathrm{CH}_{3}$ asymmetric and symmetric are located at 1481.33 and $1400.32 \mathrm{~cm}^{-1}$ respectively but the stretching and bending vibration of $\mathrm{N}-\mathrm{CH}_{3}$ appeared at 3014.74 and $1400.32 \mathrm{~cm}^{-1}$ respectively. The stretching vibration of C-N appeared at $908.47 \mathrm{~cm}^{-1}$. All bands consist as reported by Viana et al. (2012) about FTIR spectra of CTAB (Figure 4).

FTIR spectra of $\mathrm{ZnO}$ nanoparticles-CTAB are the result of interaction between leaves extract of guava seed, zinc acetate dihydrate, CTAB, and sodium hydroxide (Figure $5 \mathrm{a}-\mathrm{c}$ ). The peak between $3419-3423 \mathrm{~cm}^{-1}$ is stretching vibrations of the -O-H group (Matinise et al., 2017). The peak between $1566-1610 \mathrm{~cm}^{-1}$ is stretching vibrations of the C-O-C group (Raj and Lawerence, 2018). Stretching vibration of the C-H group (asymmetric and symmetric), $\mathrm{N}-\mathrm{CH}_{3}$ group (asymmetric and symmetric), and $\mathrm{C}-\mathrm{N}$ group in $\mathrm{ZnO}$ nanoparticlesCTAB (all types) are the stretching vibration of the group from CTAB (Viana et al., 2012). This result showed that the ZnO nanoparticles-CTAB are containing the functional groups of CTAB. The functional group of $\mathrm{Zn}-\mathrm{O}$ (stretching vibration) appeared between 617-621 cm-1 (Dobrucka and Długaszewska, 2016). This indicates that the existence of $\mathrm{Zn}-\mathrm{O}$ groups in $\mathrm{ZnO}$ nanoparticles-CTAB.

The functional groups analysis of chitosan film and film of chitosan-ZnO nanoparticles-CTAB (film I, II and III) as seen in Figure 6 and tabulated in Table 4.

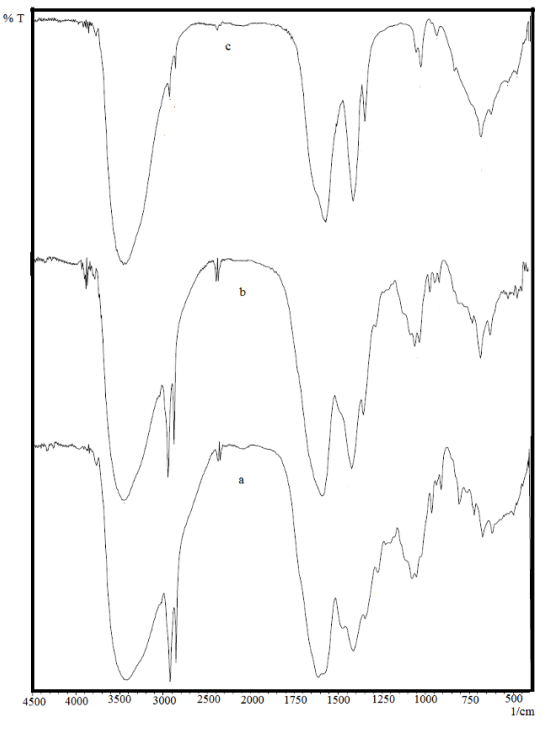

Figure 5. The Profile of FTIR Spectra $\mathrm{ZnO}$

Nanoparticles-CTAB Type A (a), Type B (a), and Type C (c)

The Figure of $6 \mathrm{a}$ is the FTIR spectra of chitosan and its main band of functional groups appeared between 1033.85$3427.51 \mathrm{~cm}^{-1}$ and it was reported by Rahman et al. (2018). The band at $3427.51 \mathrm{~cm}^{-1}$ is stretching vibration of $-\mathrm{N}-\mathrm{H}$ and $-\mathrm{O}-\mathrm{H}$ groups. Stretching vibration group of $-\mathrm{CH}_{2}$ - appeared at $2881.65-2920.23 \mathrm{~cm}^{-1}$. The stretching vibration of $-\mathrm{C}=\mathrm{O}$, -C-N- and -C-O-C- linkages groups are displayed at the band of $1595.13,1381.03$, and $1033.85 \mathrm{~cm}^{-1}$ respectively. The $\mathrm{N}-\mathrm{H}$ group appeared at $1656.85 \mathrm{~cm}^{-1}$ as bending vibration.

The FTIR spectra of the film of chitosan- $\mathrm{ZnO}$ nanoparticlesCTAB (a film I, II, and III) showed in Figure 6b-c. The band between $3427-3450 \mathrm{~cm}^{-1}$ is higher than $3427.51 \mathrm{~cm}^{-1}$ (chitosan) and it has a sharp band. The difference of this band was indicating that $\mathrm{ZnO}$ nanoparticles-CTAB bound at the primary amine groups of chitosan structure via coordination covalent bonds (Rahman et al. , 2018; Abdelhady, 2012). The functional groups of C-H at the films I, II, and II have a sharp band. There is a difference between the band of chitosan and all film. In film I, II, and III, the wavenumber of the functional group of $\mathrm{Zn}-\mathrm{O}$ appeared between $578.64-619.15 \mathrm{~cm}^{-1}$ (Prabhu et al., 2017; Santhoshkumar et al., 2017). Based on the interpretation of FTIR spectra above have proved that the $\mathrm{ZnO}$ and $\mathrm{CTAB}$ exist in the product of film chitosan- $\mathrm{ZnO}$ nanoparticles-CTAB.

\subsection{The XRD Study}

The XRD pattern of $\mathrm{ZnO}$ nanoparticles-CTAB can be seen in Figure 7, 8, and 9. The diffractogram of $\mathrm{ZnO}$ nanoparticleCTAB (type A, Figure 7a) has $2 \theta=8.60,12.60,30.00,32.91$ and $59.05^{\circ}$. There is a sharp peak at $2 \theta=32.91$ and $59.05^{\circ}$. The diffractogram of $\mathrm{ZnO}$ nanoparticles-CTAB (type B, Figure 8 a) had $2 \theta=21.17$ and $32.87^{\circ}$. A sharp peak at $2 \theta=32.87^{\circ}$. The diffractogram of $\mathrm{ZnO}$ nanoparticles-CTAB (type C, Fig- 
Table 4. Analysis of The Functional Groups Chitosan Film and Film of Chitosan-ZnO Nanoparticles-CTAB

\begin{tabular}{|c|c|c|c|c|c|}
\hline \multirow{2}{*}{ No. } & \multirow{2}{*}{$\begin{array}{c}\text { The Functional } \\
\text { Groups }\end{array}$} & \multicolumn{4}{|c|}{ Wave number $\left(\mathrm{cm}^{-1}\right)$} \\
\hline & & Chitosan film & I & $\begin{array}{l}\text { chitosan- } \\
\text { II }\end{array}$ & $\begin{array}{l}\text { oparticles-Ci IAB } \\
\text { III }\end{array}$ \\
\hline 1 & $\mathrm{O}-\mathrm{H}$ & 3427.51 & - & - & - \\
\hline 2 & $\mathrm{~N}-\mathrm{H}$ & 3427.51 & 3450.65 & 3429.43 & 3427.51 \\
\hline 3 & $\mathrm{C}-\mathrm{H}$ & $\begin{array}{c}2881.65- \\
2920.23\end{array}$ & $\begin{array}{c}2852.72- \\
2924.09\end{array}$ & $\begin{array}{c}2854.65- \\
2924.09\end{array}$ & $\begin{array}{c}2852.72- \\
2922.16\end{array}$ \\
\hline 4 & $\mathrm{~N}-\mathrm{H}$ & 1656.85 & - & - & - \\
\hline 5 & $\mathrm{C}=\mathrm{O}$ & 1595.13 & 1579.7 & 1583.56 & 1583.56 \\
\hline 6 & $\mathrm{C}-\mathrm{N}$ & 1381.03 & 1408.04 & 1409.96 & 1409.96 \\
\hline 7 & $\mathrm{C}-\mathrm{O}-\mathrm{C}$ & 1033.85 & 1022.27 & 1024.2 & 1026.13 \\
\hline 8 & $\mathrm{Zn}-\mathrm{O}$ & - & 578.64 & 619.15 & 619.15 \\
\hline
\end{tabular}

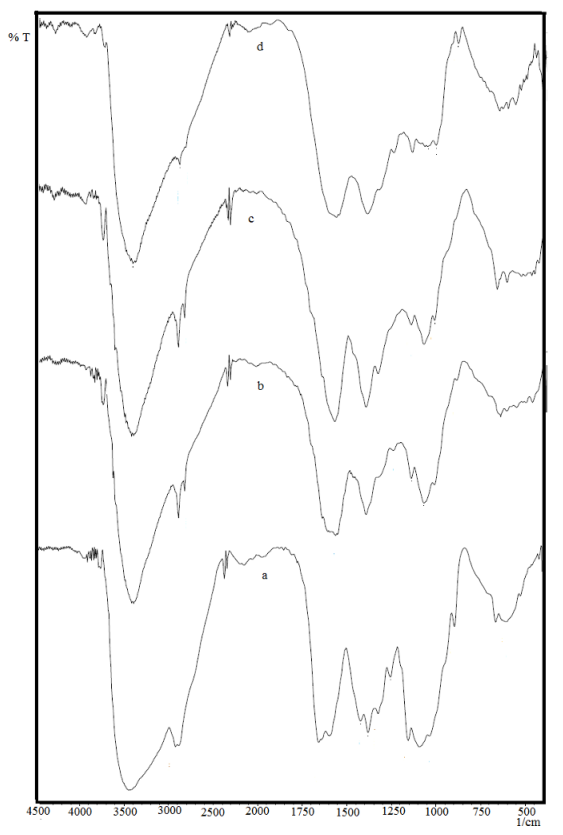

Figure 6. The Profile of FTIR Spectra Chitosan (a) and Film Chitosan-ZnO Nanoparticles-CTAB I (b), II (c) and III (c)

ure 9 a) has $2 \theta=19.10,2.18,28.00$ and $33.28^{\circ}$. The peak at $2 \theta=19.1$ and $21.18^{\circ}$ is the sharp peak. The sharp peaks at all the types of XRD pattern $\mathrm{ZnO}$ nanoparticles-CTAB were the hexagonal structure of $\mathrm{ZnO}$ (Iqbal et al., 2019). The crystallite size of the $\mathrm{ZnO}$ nanoparticles-CTAB is calculated by Debye Scherrer's formula (Vijayakumar et al., 2018).

$$
D=\left(\frac{0.9 \lambda}{\beta \cos \theta}\right)
$$

The crystallite size of the biosynthesized $\mathrm{ZnO}$ nanoparticlesCTAB type A, B, and C were estimated at 10.08, 9.31, and $1.17 \mathrm{~nm}$ respectively.

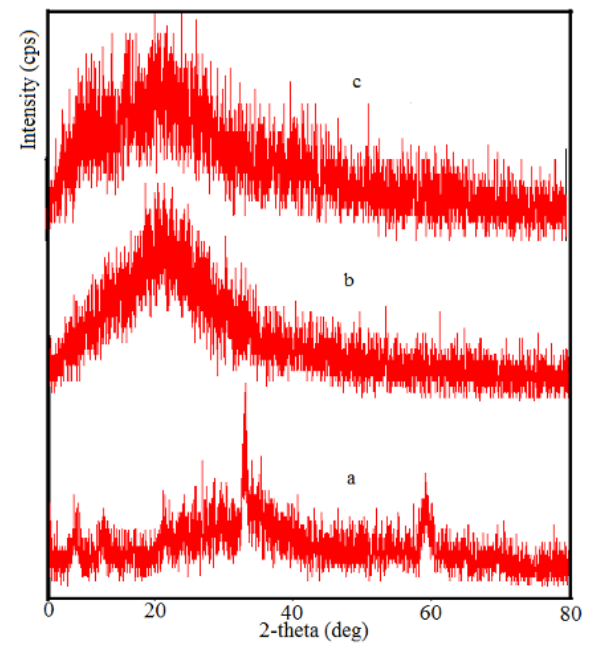

Figure 7. XRD Pattern of $\mathrm{ZnO}$ Nanoparticles-CTAB Type A (a), Chitosan Film (b), and Film of Chitosan-ZnO Nanoparticles-CTAB III (c)

The XRD pattern of chitosan film and film chitosan- $\mathrm{ZnO}$ nanoparticles-CTAB are displayed in Figure $7 \mathrm{~b}-\mathrm{c}, 8 \mathrm{~b}-\mathrm{c}$, and $9 \mathrm{~b}-\mathrm{c}$ respectively. The XRD pattern of all chitosan film has $2 \theta=14.3,20.6$ and $65.4^{\circ}$. The strongest peak appears at $2 \theta=14.3^{\circ}$ and $20.6^{\circ}$, it is assigned to (100) reflection respectively (Feng et al., 2012). The two strongest peaks showed that chitosan film at semicrystalline form Kumari et al. (2015). The diffractogram of the film chitosan- $\mathrm{ZnO}$ nanoparticles-CTAB (a film I, Figure $7 \mathrm{c}$ ) was noted at $2 \theta=10.8,16.58,21.1,27.3$, and $62.24^{\circ}$. The peak at $2 \theta=17.11^{\circ}$ appeared in the diffractogram of the film chitosan- $\mathrm{ZnO}$ nanoparticles-CTAB (film II, Figure 8c). The diffractogram of the film chitosan- $\mathrm{ZnO}$ nanoparticles-CTAB (film III, Figure 9c) was displayed at $2 \theta$ $=20.6,62.2,65.9$, and $67.8^{\circ}$. The XRD pattern of the film chitosan-ZnO nanoparticles-CTAB (a film I, II and III) has a broad peak at $2 \theta=21.1^{\circ}$ for a film I, $17.11^{\circ}$ for film II and $20.6^{\circ}$ 


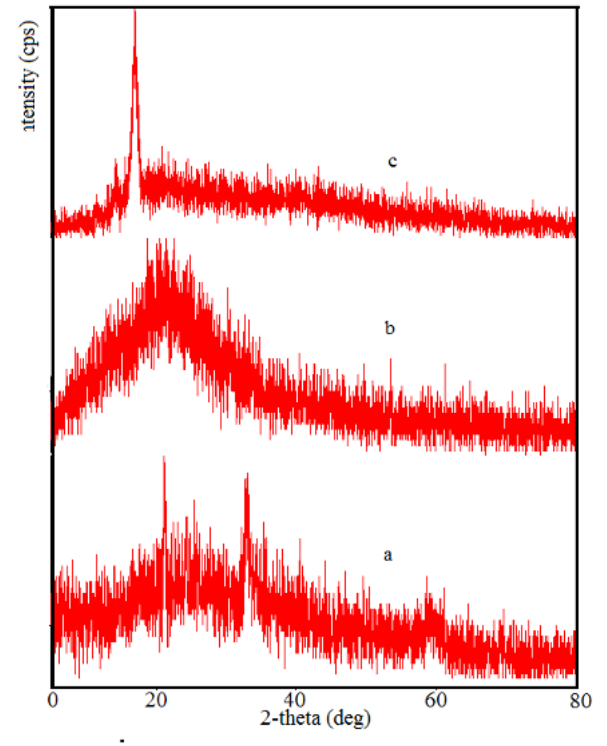

Figure 8. XRD Pattern of ZnO Nanoparticles-CTAB Type B (a), Chitosan Film (b), and Film of Chitosan-ZnO

Nanoparticles-CTAB II (c)

for film III respectively. A broad peak at all diffractograms of the film is caused by the influence of $\mathrm{ZnO}$ nanoparticles-CTAB to N-H groups of chitosan and it has an effect on the hydrogen bond at the chitosan structure, finally, it will change the orderliness of the chitosan structure (Mohamed and Fahmy, 2012). As a result, the chemical structure of chitosan changed from semicrystalline to amorph form.

\subsection{The Application of Chitosan ZnO Nanoparticles-CTAB Film as Antibacterial}

The clear zone of the film of chitosan- $\mathrm{ZnO}$ nanoparticlesCTAB was investigated as shown in Figure 10 and the calculation of the inhibition zone was tabulated in Table 5 .

Table 5. The Calculation of Inhibition Zone of Compound

\begin{tabular}{ccccc}
\hline \multirow{2}{*}{ Compounds } & \multicolumn{5}{c}{ The inhibition zone (mm) of compounds in the petri dishes: } \\
& I & II & III & average \pm SD \\
\hline A & 14.72 & 9.1 & 12.04 & $11.95 \pm 2.30$ \\
B & 10.57 & 13.1 & 10.25 & $11.31 \pm 1.27$ \\
C & 10.37 & 10.68 & 10.08 & $10.38 \pm 0.24$ \\
D & 9.75 & 10.28 & 11.08 & $10.37 \pm 0.55$ \\
E & 0 & 0 & 0 & 0 \\
F & 0 & 0 & 0 & 0 \\
G & 0 & 0 & 0 & 0 \\
H & 16.05 & 13.25 & 12.58 & $13.96 \pm 1.51$ \\
\hline
\end{tabular}

The average inhibition zone of film I (D), III (C), and II (B) against $S$. aureus bacteria were $10.37 \pm 0.55,10.38 \pm 0.24$, and $11.31 \pm 1.27 \mathrm{~mm}$ respectively but the average inhibition zone of the film II (A, wet film, this film was dipped in sterile aqua dest) is higher than all film. Chitosan film (E, chitosan film was dipped in sterile aqua dest) and $\mathrm{F}$ did not have the inhibition zone to $S$. aureus bacteria. Sterile aqua dest $(\mathrm{G})$ did not have

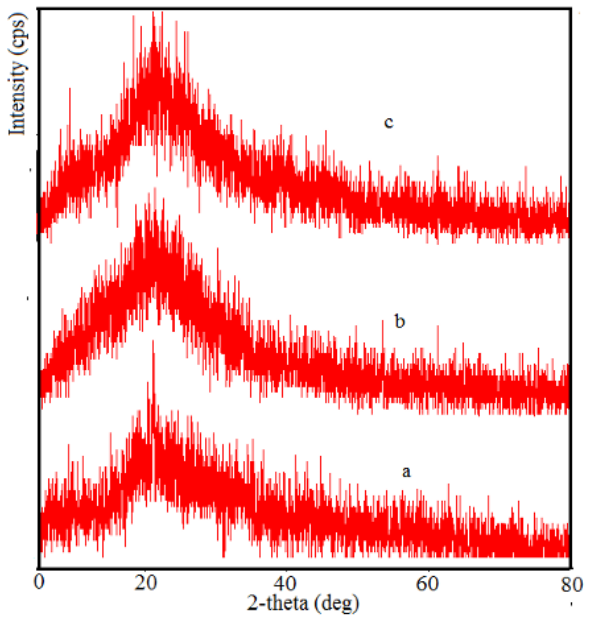

Figure 9. XRD Pattern of ZnO Nanoparticles-CTAB Type C (a), Chitosan Film (b), and Film of Chitosan-ZnO Nanoparticles-CTAB III (c)
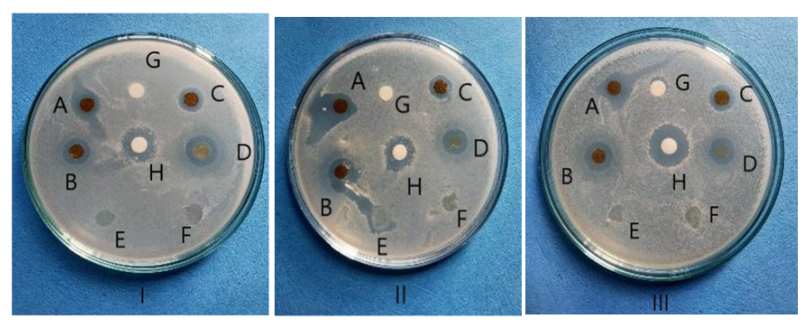

Figure 10. The Photograph of The Clear Zone of Film II (Wet, A), Film II (Dry, B), Film III (Dry, C), Film I (Dry, D), Chitosan Film (Wet, E), Chitosan Film (Dry, F), Sterile Aquadest (G) and Amoxicillin (1000 ppm, H)

the inhibition zone but the amoxicillin $(\mathrm{H})$ has the inhibition zone to $S$. aureus bacteria.

The film I, II, and III can inhibit the growth of bacterial. There is an effect of $\mathrm{ZnO}$ nanoparticles-CTAB on chitosan. The antimicrobial mechanism of the film of chitosan modified $\mathrm{ZnO}$ nanoparticles-CTAB as reported by El-Fawala et al. (2020): the outer cell wall of S.aureus has pores and the $\mathrm{ZnO}$ can go on these pores. This argument is explained by Rahman et al. (2018) that the cell wall of bacteria has a negative charge. On other hand, the positive charge of zinc (II) ion, the reactive oxygen species, and the surface of chitosan modified $\mathrm{ZnO}$ nanoparticles will have interacted with a negative charge of bacteria through electrostatic interaction and as a result, the process of protein synthesis of bacteria will be disturbed (Dananjaya et al., 2018). Finally, there is an effect of the CTAB. The penetration to the negatively charged bacterial cell wall was enhanced by the overall positive charge of the $\mathrm{ZnO}$ nanoparticles-CTAB (Jang et al., 2015) and CTAB as a biocidal activity against $S$. aureus (Khanmirzaee et al., 2020). 
The average inhibition zone of chitosan film is zero and is supported by the literature of Foster and Butt (2011) and Sharma et al. (2012). They reported that the chitosan in the film form does not interact with the cell wall and it can not inhibit the growth of bacterial.

\section{CONCLUSIONS}

Aqueous extract of leaves guava seed, CTAB, sodium hydroxide, and $\mathrm{Zn}\left(\mathrm{CH}_{3} \mathrm{COO}\right)_{2} .2 \mathrm{H}_{2} \mathrm{O}$ solution as materials for biosynthesis of $\mathrm{ZnO}$ nanoparticles-CTAB. $\mathrm{ZnO}$ nanoparticles-CTAB can be reacted with chitosan form a chitosan- $\mathrm{ZnO}$ nanoparticlesCTAB film. The existence of $\mathrm{Zn}-\mathrm{O}$ group and $\mathrm{C}-\mathrm{H}$ in the structure of the chitosan- $\mathrm{ZnO}$ nanoparticles-CTAB film. The chitosan-ZnO nanoparticles-CTAB film can be used as the antibacterial agent of $S$. aureus bacteria.

\section{ACKNOWLEDGEMENT}

This research was funded by Bhakti Pertiwi High School of Pharmacy Science.

\section{REFERENCES}

Abdelhady, M. (2012). Preparation and characterization of chitosan/zinc oxide nanoparticles for imparting antimicrobial and UV protection to cotton fabric. International Journal of Carbohydrate Chemistry, 12; 1-6

Abdi, S. and D. Dorranian (2018). Effect of CTAB concentration on the properties of $\mathrm{ZnO}$ nanoparticles produced by laser ablation method in CTAB solution. Optics \& Laser Technology, 108; 372-377

Al-Thabaiti, S. A., A. Y. Obaid, S. Hussain, and Z. Khan (2015). Shape-directing role of cetyltrimethylammonium bromide on the morphology of extracellular synthesis of silver nanoparticles. Arabian Journal of Chemistry, 8(4); 538544

Benhabiles, M. S, H. Lounici, N. Drouiche, M. F. A. Goosen and N. Mameri (2012). Antibacterial activity of chitin, chitosan and its oligomers prepared from shrimp shell waste. Food Hydrocolloids, 29(1); 48-56

Brasselet, C., G. Pierre, P. Dubessay, M. Dols-Lafargue, J. Coulon, J. Maupeu, A. Vallet-Courbin, H. De Baynast, T. Doco, P. Michaud, et al. (2019). Modification of chitosan for the generation of functional derivatives. Applied Sciences, 9(7); 1321

Cheba, B. A.(2020). Chitosan: Properties, Modifications and Food Nanobiotechnology Chitosan: Properties, Modifications and Food Nanobiotechnology. Procedia Manuf, 46; $652-658$

Chen, C. H., Y. C. Lin, C. F. Mao, and W. T. Liao (2019). Green synthesis, size control, and antibacterial activity of silver nanoparticles on chitosan films. Research on Chemical Intermediates, 45(9); 4463-4472

Dananjaya, S., R. S. Kumar, M. Yang, C. Nikapitiya, J. Lee, and M. De Zoysa (2018). Synthesis, characterization of ZnOchitosan nanocomposites and evaluation of its antifungal activity against pathogenic Candida albicans. International Journal of Biological Macromolecules, 108; 1281-1288

Daphedar, A. and T. C. Taranath (2018). Green synthesis of zinc nanoparticles using leaf extract of Albizia saman (Jacq.) Merr. and their effect on root meristems of Drimia indica (Roxb.) Jessop. International Journal of Cytology, Cytosystematics and Cytogenetics, 71(2); 93-102

Dobrucka, R. and J. Długaszewska (2016). Biosynthesis and antibacterial activity of $\mathrm{ZnO}$ nanoparticles using Trifolium pratense flower extract. Saudi Journal of Biological Sciences, 23; 517-523

El-Fawala. G, H. Honga, X. Songa, J. Wua, M. Suna, C. Hea, X. Moa, Y. Jiang, and H. Wang (2020). Fabrication of antimicrobial films based on hydroxyethylcellulose and $\mathrm{ZnO}$ for food packaging application Food Packaging and Shelf Life, 23; 100462

Estevam, L. d. S., H. S. Debone, C. M. P. Yoshida, and C. Da Silva (2012). Adsorption of bovine serum and bovine haemoglobin onto chitosan film. Adsorption Science \& Technology, 30(9); 785-792

Fatoni, A., A. C. Paramita, B. Untari and N. Hidayati(2020). Chitosan-CuO Nanoparticles as antibacterial shigella dysentriae: synthesis, characterization and in vitro study. Jurnal Kimia Sains dan Aplikasi, 23(12); 432-439

Fatoni, A., M. A. Afrizal, A. A. Rasyad, and N. Hidayati (2021). $\mathrm{ZnO}$ Nanoparticles and Its Interaction With Chitosan: Profile Spectra and Their Activity Against Bacterial. Jurnal Kimia dan Pendidikan Kimia, 6(2); 216-227

Fatoni, A., H. Hilma, A. A. Rasyad, S. Novriyanti, and N. Hidayati (2020a). Biosintesis ZnO Nanopartikel dari ekstrak air daun jambu biji (Psidium guajava $L$ ) dan ion $\mathrm{Zn}^{2+}$ serta interaksinya dengan kitosan sebagai antibakteri Escherichia coli. Jurnal Sains Farmasi \& Klinis, 7(2); 151-157 (in Indonesia)

Fatoni, A., E. Munarsih, K. Asmadi, and N. Hidayati (2020b). Synthesis and characterization Chitosan- $\mathrm{ZnO}$ nanoparticle and its application as antibacterial Agent of Staphylococus aureus ATCC 25923. Science and Technology Indonesia, 2(1); $1-5$

Fatoni, A., R. A. Habiba, and N. Hidayati (2021). CuO Nanoparticles: Biosynthesis, characterization and in vitro study. Science and Technology Indonesia, 6(1); 25-29

Feng, F., Y. Liu, B. Zhao and K. Hu (2012). Characterization of half $\mathrm{N}$-acetylated chitosan powders and films. Procedia Engineering, 27; 1718-1722

Foster, L. J. R. and J. Butt (2011). Chitosan films are NOT antimicrobial. Biotechnology Letters, 33(2); 417-421

Geetha, D. and T. Thilagavathi (2010). Hydrothermal synthesis of nano $\mathrm{ZnO}$ structures from CTAB. Digest Journal of Nanomaterials and Biostructures, 5(1); 297-301

Goy, R. C, S.T.B. Morais, and O.B.G. Assis (2016). Evaluation of the antimicrobial activity of chitosan and its quaternized derivative on E. coli and S. aureus growth. Revista Brasileira Farmacognosia, 26; 122-127

Guivar, J. A. R., E. A. Sanches, C. J. Magon, and E. G. R. Fernandes (2015). Preparation and characterization 
of cetyltrimethylammonium bromide (CTAB)-stabilized $\mathrm{Fe}_{3} \mathrm{O}_{4}$ nanoparticles for electrochemistry detection of citric acid. Journal of Electroanalytical Chemistry, 755; 158-166

Hajji, S., S. B. Khedir, I. Hamza-Mnif, M. Hamdi, I. Jedidi, R. Kallel, S. Boufi, and M. Nasri (2019). Biomedical potential of chitosan-silver nanoparticles with special reference to antioxidant, antibacterial, hemolytic and in vivo cutaneous wound healing effects. Biochimica et Biophysica Acta (BBA)General Subjects, 1863(1); 241-254

Haldorai, Y. and J. J. Shim (2013). Multifunctional chitosancopper oxide hybrid material: photocatalytic and antibacterial activities. International Journal of Photoenergy, 2013

Ibrahim, H. M. (2015). Green synthesis and characterization of silver nanoparticles using banana peel extract and their antimicrobial activity against representative microorganisms. Journal of Radiation Research and Applied Sciences, 8(3); 265275

Iqbal, S., M. Fakhar, M. Atif, N. Ahmed, N. Amin, A. Hanif, W. A. Farooq, et al. (2019). Empirical modeling of $\mathrm{Zn} / \mathrm{Zno}$ nanoparticles decorated/conjugated with fotolon (chlorine e6) based photodynamic therapy towards liver cancer treatment. Micromachines, 10(1); 60

Isnaeni, I., E. Hendradi, and N. Z. Zettira (2020). Inhibitory effect of roselle aqueous extracts-HPMC $6000 \mathrm{gel}$ on the growth of Staphylococcus aureus ATCC 25923. Turkish Journal of Pharmaceutical Sciences, 17(2); 190

Jang, H., S. H. Lim, J. S. Choi, and Y. Park (2015). Antibacterial properties of cetyltrimethylammonium bromidestabilized green silver nanoparticles against methicillinresistant Staphylococcus aureus. Archives of Pharmacal Research, 38(10); 1906-1912

Jayasuriya, A. C., A. Aryaei, and A. H. Jayatissa (2013). ZnO nanoparticles induced effects on nanomechanical behavior and cell viability of chitosan films. Materials Science and Engineering: $C$, 33(7); 3688-3696

Joseph, L., M. George, G. Singh, and P. Mathews (2016). Phytochemical investigation on various parts of Psidium guajava. Annals of Plant Sciences, 52; 1265-1268

Junior, E. A. A., F. X. Nobre, G. da Silva Sousa, L. S. Cavalcante, M. R. d. M. C. Santos, F. L. Souza, and J. M. E. de Matos (2017). Synthesis, growth mechanism, optical properties and catalytic activity of $\mathrm{ZnO}$ microcrystals obtained via hydrothermal processing. Royal Society of Chemistry Advances, 7(39); 24263-24281

Khan, M. F., A. H. Ansari, M. Hameedullah, E. Ahmad, F. M. Husain, Q. Zia, U. Baig, M. R. Zaheer, M. M. Alam, A. M. Khan, et al. (2016). Sol-gel synthesis of thorn-like $\mathrm{ZnO}$ nanoparticles endorsing mechanical stirring effect and their antimicrobial activities: Potential role as nano-antibiotics. Scientific Reports, 6(1); 1-12

Khan, Z., J. I. Hussain, and A. A. Hashmi (2012). Shapedirecting role of cetyltrimethylammonium bromide in the green synthesis of Ag-nanoparticles using Neem (Azadirachta indica) leaf extract. Colloids and Surfaces B: Biointerfaces, 95; 229-234
Khalil, M. M. H., , E. H. Ismail, , K. Z. El-Baghdady, and D. Mohamed (2014). Green synthesis of silver nanoparticles using olive leaf extract and its antibacterial activity. Arabian Journal of Chemistry, 7; 1131-1139

Khanmirzaee, S., M. Montazer, and A. Pashaee (2020). Dyeing of cotton fabric with antibacterial properties using direct dye and CTAB. Journal of Natural Fibers, 17(2); 223-234

Kumari, S., P. Rath, A. S. H. Kumar, and T. Tiwari (2015). Extraction and characterization of chitin and chitosan from fishery waste by chemical method. Environmental Technology \& Innovation, 3 ; 77-85

Matinise. N, X.G. Fuku, K. Kaviyarasu, N. Mayedwa and M. Maaza (2017). ZnO nanoparticles via Moringa oleifera green synthesis: Physical properties \& mechanism of formation. Applied Surface Science, 406(1); 77-85

Medina, J., H. Bolaños, L. P. Mosquera-Sanchez, and J. Rodriguez-Paez (2018). Controlled synthesis of $\mathrm{ZnO}$ nanoparticles and evaluation of their toxicity in Mus musculus mice. International Nano Letters, 8(3); 165-179

Mohamed, N. A. and M. M. Fahmy (2012). Synthesis and antimicrobial activity of some novel cross-linked chitosan hydrogels. International Journal of Molecular Sciences, 13(9); 11194-11209

Muinde, V. M., J. M. Onyari, B. Wamalwa, and J. N. Wabomba (2020). Adsorption of malachite green dye from aqueous solutions using mesoporous chitosan-zinc oxide composite material. Environmental Chemistry and Ecotoxicology, 2; 115125

Nainggolan, I., H. Agusnar, Z. Alfian, et al. (2020). The characterization of chitosan- $\mathrm{ZnO}$ nanoparticles modified screenprinted copper electrodes as the analytical sensor. In Journal of Physics: Conference Series, 1542; 012053

Narayanan, G. N. and A. Karthigeyan (2016). Influence of different concentrations of Cetyltrimethylammonium bromide on morphological, structural and optical properties of Zinc Oxide nanorods. Materials Today: Proceedings, 3(6); $1762-1767$

Nasrollahzadeh, M., S. S. Momeni, and S. M. Sajadi (2017). Green synthesis of copper nanoparticles using Plantago asiatica leaf extract and their application for the cyanation of aldehydes using $\mathrm{K}_{4} \mathrm{Fe}(\mathrm{CN})_{6}$. Journal of Colloid and Interface Science, 506; 471-477

Prabhu, Y., K. V. Rao, V. S. Sai, and T. Pavani (2017). A facile biosynthesis of copper nanoparticles: a micro-structural and antibacterial activity investigation. Journal of Saudi Chemical Society, 21(2); 180-185

Preethi, S., K. Abarna, M. Nithyasri, P. Kishore, K. Deepika, R. Ranjithkumar, V. Bhuvaneshwari, and D. Bharathi (2020). Synthesis and characterization of chitosan/zinc oxide nanocomposite for antibacterial activity onto cotton fabrics and dye degradation applications. International Journal of Biological Macromolecules, 164; 2779-2787

Qiu, B., X. F. Xu, R. H. Deng, G. Q. Xia, X. F. Shang, and P. H. Zhou (2019). Construction of chitosan/ZnO nanocomposite film by in situ precipitation. International Journal of Biological 
Macromolecules, 122; 82-87

Rahman, P. M., V. M. Mujeeb, K. Muraleedharan, and S. K. Thomas (2018). Chitosan/nano $\mathrm{ZnO}$ composite films: Enhanced mechanical, antimicrobial and dielectric properties. Arabian Journal of Chemistry, 11(1); 120-127

Raj, A. and R. Lawerence (2018). Green synthesis and charcterization of zno nanoparticles from leafs extracts of rosa indica and its antibacterial activity. Rasayan Journal of Chemistry, 11(3); 1339-1348

Ramimoghadam, D., M. Z. B. Hussein, and Y. H. Taufiq-Yap (2012). The effect of sodium dodecyl sulfate (SDS) and cetyltrimethylammonium bromide (CTAB) on the properties of $\mathrm{ZnO}$ synthesized by hydrothermal method. International Journal of Molecular Sciences, 13(10); 13275-13293

Rodrigues, D. A., J. M. Moura, G. L. Dotto, T. R. Cadaval, and L. A. Pinto (2018). Preparation, characterization and dye adsorption/reuse of chitosan-vanadate films. Journal of Polymers and The Environment, 26(7); 2917-2924

Santhoshkumar, J., S. V. Kumar, and S. Rajeshkumar (2017). Synthesis of zinc oxide nanoparticles using plant leaf extract against urinary tract infection pathogen. Resource Efficient Technologies, 3(4); 459-465

Sharma, S., P. Sanpui, A. Chattopadhyay, and S. S. Ghosh (2012). Fabrication of antibacterial silver nanoparticle sodium alginate-chitosan composite films. Royal Science of Chemistry Advances, 2(13); 5837-5843
Siboni, M. S, A. Khataee, A. Hassani, and S. Karaca (2015). Preparation, characterization and application of a CTABmodified nanoclay for the adsorption of an herbicide from aqueous solutions: Kinetic and equilibrium studies. Comptes Rendus Chimie, 18(2); 204-214

Tamuly, C., M. Hazarika, R. Debnath, R. Saikia, M. Bordoloi, J. Bora, and M. R. Das (2013). Effect of CTAB in biosynthesis of Au-nanoparticles using Gymnocladus assamicus and its biological evaluation. Materials Letters, 113; 103-106

Usman, M. S., N. A. Ibrahim, K. Shameli, N. Zainuddin, and W. M. Z. W. Yunus (2012). Copper nanoparticles mediated by chitosan: synthesis and characterization via chemical methods. Molecules, 17(12); 14928-14936

Viana, R. B., A. B. Da Silva, and A. S. Pimentel (2012). Adsorption of sodium dodecyl sulfate on ge substrate: the effect of a low-polarity solvent. International Journal of Molecular Sciences, 13(7); 7980-7993

Vijayakumar, S., S. Mahadevan, P. Arulmozhi, S. Sriram, and P. Praseetha (2018). Green synthesis of zinc oxide nanoparticles using Atalantia monophylla leaf extracts: Characterization and antimicrobial analysis. Materials Science in Semiconductor Processing, 82; 39-45

Wu, H. and J. Zhang (2018). Chitosan-based zinc oxide nanoparticle for enhanced anticancer effect in cervical cancer: A physicochemical and biological perspective. Saudi Pharmaceutical Journal, 26(2); 205-210 